\title{
ASPECTS OF DIAGNOSTICS OF NEONATAL PULMONARY HYPERTENSION IN THE PREMATURE NEWBORNS
}

\author{
CShkarin N., ORCID: 0000-0002-2186-7362, Mordovia State University, \\ Saransk, Russia,n.shkarin2018@gmail.com \\ CNaumenko E., M.D., Mordovia State University, Saransk, Russia, \\ ei-naumenko@yandex.ru
}

\section{АСПЕКТЫ ДИАГНОСТИКИ НЕОНАТАЛЬНОЙ ЛЕГОЧНОЙ ГИПЕРТЕНЗИИ У НЕДОНОШЕННЫХ НОВОРОЖДЕННЫХ}

\author{
(СШкарин Н. С., ORCID: 0000-0002-2186-7362, Наџиональный исследовательский \\ Мордовский государственный университет им. Н.П. Огарева, \\ 2. Саранск, Россия, n.shkarin2018@gmail.com \\ (СНауменко Е. И., канд. мед. наук, Начиональный исследовательский \\ Мордовский государственный университет им. Н.П. Огарева, \\ 2. Саранск, Россия, ei-naumenko@yandex.ru
}

Abstract. The formation of the pulmonary vascular system is due to the gradual development and is an integral part of the differentiation of the cardiovascular and pulmonary systems. In children born at a gestational age of 24 weeks, the lungs are at the canalicular stage of formation. At this stage, the alveoli and capillaries are not capable of ensuring proper gas exchange, due to failures in the remodeling of the interstitial extracellular matrix. Hypoxia and, as a result, posthypoxic changes eventually lead to maladaptation syndrome of the cardiovascular system caused by a cascade of various disorders. One, perhaps, of the most severe clinic-pathogen etic forms of this pathology is neonatal pulmonary hypertension, characterized by the absence of specific manifestations, pathognomonic signs and accompanied by high mortality. The purpose of our study is to analyze the data of ECG and echocardiogram in children with neonatal pulmonary hypertension. We found that with persistent pulmonary hypertension on an ECG, signs of hypoxicischemic myocardial damage are more often detected. With persistent pulmonary hypertension, speeds of more than $1.4-1.6 \mathrm{~m} / \mathrm{s}$ and diagnostically significant regurgitation to the tricuspid valve $(++/+++)$ are detected.

Аннотация. Формирование легочно-сосудистой системы обусловлено поэтапным развитием и является неотъемлемой частью дифференцировки сердечно-сосудистой и легочной систем. У детей, родившихся на сроке гестации 24 недели легкие находятся на каналикулярной стадии формирования. При этой стадии альвеолы и капилляры не способы обеспечить должным образом газообмен, ввиду сбоев в ремоделировании инстерциального внеклеточного матрикса. Гипоксия и как следствие постгипоксические изменения в итоге ведут к синдрому дезадаптации сердечно-сосудистой системы, обусловленного каскадом различных нарушений. К одной, пожалуй, из самых тяжелых клинико-патогенетических форм данной патологии относится неонатальная легочная гипертензия, характеризующаяся отсутствием специфических проявлений, патогномоничных признаков и сопровождающаяся высокой летальностью. Цель исследования — провести анализа данных ЭКГ и ЭХО-КГ у детей с неонатальной легочной гипертензией. Нами установлено, что при персистирующей 
легочной гипертензии на ЭКГ чаще обнаруживаются признаки гипоксически-ишемического поражения миокарда. При персистирующей легочной гипертензии выявляются скоростные потоки свыше 1,4-1,6 м/с и диагностически значимая регургитация на трикуспидальный клапан $(++/+++)$.

Keywords: neonatal pulmonary hypertension, children, ECG, Echocardiography.

Ключевые слова: неонатальная легочная гипертензия, дети, ЭКГ, ЭхоКГ.

Traditionally, there are 5 stages of lung formation (development): embryonic, pseudoglandular, canalicular, saccular, alveolar [1, p. 124]. The formation of the pulmonary vascular system is due to the gradual development and is an integral part of the differentiation of the cardiovascular and pulmonary systems [2, p. 471]. In case of prematurity, the physiology of the development of the lungs is disturbed [3, p. 43], which is in direct correlation with the degree of prematurity. In children born at a gestational age of 24 weeks, the lungs are at the canalicular stage of formation [4, p. 80]. At this stage, the alveoli and capillaries are not capable of ensuring proper gas exchange, due to failures in the remodeling of the interstitial extracellular matrix. Premature exposure to the extrauterine environment and the initiation of mechanical ventilation lead to inflammation and the formation of oxidative stress with the formation of atomic oxygen and peroxides, all of which leads to hypoxia. The scientific literature suggests that post-hypoxic complications of the cardiovascular system occur in 40-70\%. Hypoxia and, as a result, posthypoxic changes eventually lead to maladaptation syndrome of the cardiovascular system caused by a cascade of various disorders.

One, perhaps, of the most severe clinic-pathogenetic forms of this pathology is neonatal pulmonary hypertension, characterized by the absence of specific manifestations, pathognomonic signs and accompanied by high mortality [5, p. 740].

The aim of the work is to conduct a structural analysis of ECG and echocardiogram data in children with neonatal pulmonary hypertension.

\section{Materials and methods}

Analyzed the results of ECG and ECHO-KG data on 140 newborns. Criteria for the selection of children: newborns (full-term and preterm) with mild primary pulmonary hypertension identified. The first group, $\mathrm{n}=70$, included children with neonatal pulmonary hypertension -35 preterm and 35 full-term; the second (control group) included 70 children without neonatal pulmonary hypertension (35 full-term and 35 premature). Exclusion criteria are: severe primary pulmonary hypertension, pneumonia and pulmonary pathology, congenital heart defects, and other organic heart disease.

\section{Results and discussion}

During the analysis of the ECG results, we found that the prevailing number of newborns (Figure) did not have ECG abnormalities (70\%). 
@Norma $\square$ Tachyarrhythmia $\square$ Bradyarrhythmia
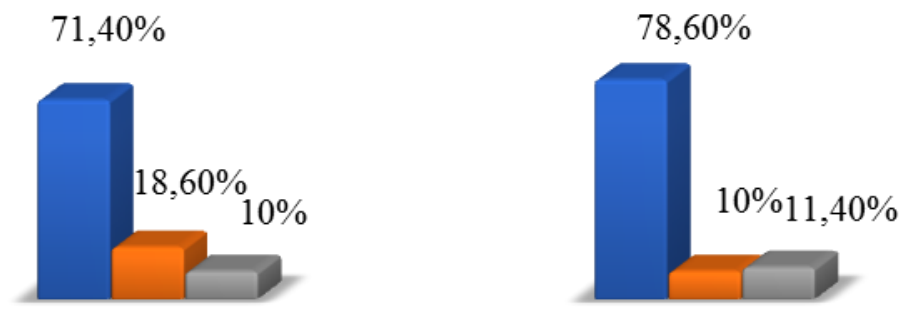

Children with primary pulmonary hypertension

Control group

Figure. The frequency of occurrence of rhythm disturbances (\%).

The main pacemaker is the sinus node; the electrical axis of the heart in all children in the range of the age norm corresponds to the physiology of the features. The disease of electrical systole in children in the study was not detected, an imbalance of electrical myocardium was found to decrease the voltage of the QRS complex in only 4 children in the second group and 6 premature infants in the 1st group. All children segment ST on the contour. 14.3\% of STs of children revealed a deviation of the segment of the 1st group, and more and more often in premature babies (20\%). Twave more often in children of the first group, $31.4 \%$ is reliable with $p>0.05$, without significant differences in full-term and premature babies. In $17.1 \%$ of cases, note an overload of the right ventricle, the same frequency in full-term and premature babies (Table 1). Recorded rhythm disturbances: sinus tachycardia, bradycardia, without confidence in both groups.

Table 1.

THE RATIO OF ECG INDICATORS IN GROUPS ( $p>0.05)$

\begin{tabular}{ccccc}
\hline \multirow{2}{*}{ Indicator } & \multicolumn{2}{c}{$\begin{array}{c}\text { Children with primary pulmonary } \\
\text { hypertension }\end{array}$} & \multicolumn{2}{c}{ Control } \\
\hline Heart rate & Full-term children & Premature babies & Full-term children & Premature babies \\
\hline Heart rate & $142 \pm 2.9$ & $146 \pm 3.6$ & $136 \pm 2.7$ & $143 \pm 3.0$ \\
QT & $0.26 \pm 0.008$ & $0.28 \pm 0.005$ & $0.26 \pm 0.007$ & $0.28 \pm 0.006$ \\
QT s & $399.6 \pm 8.8$ & $428.9 \pm 9.6$ & $400.1 \pm 8.3$ & $418.7 \pm 9.8$ \\
\hline
\end{tabular}

In $11.5 \%$ of newborns of the 1st group, instability was detected: incomplete blockade of the right bundle of His $(n=6,8.6 \%)$, slowing of the AV-conduction $(n=2,2.9 \%)$, with the same frequency as in full-term and premature babies $(p>0.05)$.

Thus, on the ECG in children of the studied group, the characteristics of hypoxic-ischemic pathology of the myocardium were more often identified; instability of conduction - incomplete blockade of the right leg of the bundle of His and slowing down of AV conduction. Detect rhythm instability: sinus tachycardia, with an increase, and sinus bradycardia, in children register the right ventricular overload. These symptoms manifest themselves in the same way in both groups, however, in premature babies, due to the structural and functional inferiority, to fix the underestimation of the QRS voltage.

According to the results of echocardiography, an analysis of the characteristics of the systolic function of the left ventricle (end-diastolic size, ejection fraction, fractional shortening of left ventricular myocardial fibers) was made. Evaluated the size of the cavities of the heart centile 
tables. According to the data obtained, the dimensions of the cavities corresponded to the physiology norms in both groups (Table 2).

Table 2.

THE DIMENSIONS OF THE CAVITIES OF THE HEART

\begin{tabular}{lcccc}
\hline \multirow{1}{*}{ Indicator } & \multicolumn{2}{c}{$\begin{array}{c}\text { Children with primary pulmonary } \\
\text { hypertension }\end{array}$} & \multicolumn{2}{c}{ Control } \\
\cline { 2 - 5 } & $\begin{array}{c}\text { Full-term } \\
\text { children }\end{array}$ & $\begin{array}{c}\text { Premature } \\
\text { babies }\end{array}$ & $\begin{array}{c}\text { Full-term } \\
\text { children }\end{array}$ & $\begin{array}{c}\text { Premature } \\
\text { babies }\end{array}$ \\
\hline $\begin{array}{l}\text { Of course - diastolic size of } \\
\text { the left ventricle }\end{array}$ & $19.9 \pm 0.41$ & $17.2 \pm 0.38$ & $17.3 \pm 0.59$ & $16.1 \pm 0.33$ \\
$\begin{array}{l}\text { Of course - diastolic size of } \\
\text { the right ventricle }\end{array}$ & $10.1 \pm 0.2$ & $8.7 \pm 0.23$ & $9.6 \pm 0.17$ & $8.5 \pm 0.22$ \\
Left atrium & $12.5 \pm 0.27$ & $10.8 \pm 0.27$ & $11.01 \pm 0.35$ & $10.58 \pm 0.32$ \\
Right atrium & $14.5 \pm 0.26$ & $12.8 \pm 0.23$ & $13.15 \pm 0.33$ & $12.69 \pm 0.35$ \\
\hline
\end{tabular}

The mean indices of the ejection fraction and fractional shortening of the left ventricular myocardium fibers were of great importance but did not exceed the age limits (Table 3 ).

\section{INDICATORS OF EJECTION FRACTION/FRACTIONAL SHORTENING OF MYOCARDIAL FIBERS}

Table 3.

\begin{tabular}{ccccc}
\hline \multirow{2}{*}{ Indicator } & \multicolumn{2}{c}{$\begin{array}{c}\text { Children with primary pulmonary } \\
\text { hypertension }\end{array}$} & \multicolumn{2}{c}{ Control } \\
\cline { 2 - 5 } & Full-term children & Premature babies & Full-term children & Premature babies \\
\hline $\mathrm{FI}(\%)$ & $70.5 \pm 0.67$ & $68.2 \pm 1.26$ & $68.9 \pm 1.57$ & $70.6 \pm 1.27$ \\
$\Delta \mathrm{S}(\%)$ & $37.1 \pm 0.64$ & $36.7 \pm 0.78$ & $36.3 \pm 1.22$ & $37.1 \pm 1.04$ \\
\hline
\end{tabular}

Myocardial diastolic dysfunction was recorded in $34.3 \%$ of the children in the study group, without significant differences in full-term and premature babies. The main manifestation was a decrease in the speed of diastolic filling, the predominance of blood flow to atrial filling $(\mathrm{E} / \mathrm{A}<1)$. $17(70.8 \%)$ children of the 1st group had diastolic dysfunction of the pancreas, less often -7 (29.2\%) children had diastolic dysfunction of the left ventricle and right ventricle. In $100 \%$ of cases, persistence of fetal communications was noted. In all children, blood shunting was visualized through MPS, the average size of which in full-term children with primary pulmonary hypertension was $3.1 \pm 0.19 \mathrm{~mm}$, in premature children with primary pulmonary hypertension was $3.9 \pm 0.48 \mathrm{~mm}$ (in the control group: full-term babies $-2.9 \pm 0.2 \mathrm{~mm}$; in premature babies $-3.7 \pm 0.7 \mathrm{~mm}$ ). $42.8 \%$ of the children in the study group had fetal communications with sizes $>3 \mathrm{~mm}, \mathrm{p}>0.05$, with no significant differences in full-term babies and premature babies. A functioning full-term children was detected in $7(10 \%)$ children of the 1 st group and in $3(4.3 \%)$ from the 2 nd $(p>0.05)$.

Primary pulmonary hypertension is characterized by a high velocity flow in the pulmonary artery stem of $1.4-1.6 \mathrm{~m} / \mathrm{s}$ in full-term children, $>1.6 \mathrm{~m} / \mathrm{s}$ in premature babies, and this was found in the study. The pressure gradient in the pulmonary artery stem is 2 times higher in newborns with primary pulmonary hypertension, and in premature babies this indicator was slightly higher than in full-term children. When comparing these indicators (Table 4), high reliability of differences between groups was found ( $p<0.001)$. 
THE RATIO OF VELOCITY FLOWS AND THE PRESSURE GRADIENT

Table 4. ON THE PULMONARY TRUNK

Children with primary pulmonary

\begin{tabular}{lccc|c|}
\hline \multicolumn{1}{c}{} & \multicolumn{1}{c}{$\begin{array}{c}\text { Children with primary pulmonary } \\
\text { hypertension }\end{array}$} & \multicolumn{2}{c}{ Control } \\
\cline { 2 - 5 } & $\begin{array}{c}\text { Full-term } \\
\text { children }\end{array}$ & $\begin{array}{c}\text { Premature } \\
\text { babies }\end{array}$ & $\begin{array}{c}\text { Full-term } \\
\text { children }\end{array}$ & $\begin{array}{c}\text { Premature } \\
\text { babies }\end{array}$ \\
\hline $\begin{array}{l}\text { Vmax the trunk of the pulmonary } \\
\begin{array}{l}\text { artery (mm/s). } \\
\text { pG the trunk of the pulmonary }\end{array}\end{array}$ & $1.86 \pm 0.04$ & $1.96 \pm 0.06$ & $1.34 \pm 0.07$ & $1.26 \pm 0.08$ \\
artery (mm Hg) & $14.5 \pm 0.6$ & $17.1 \pm 1.24$ & $7.34 \pm 0.71$ & $7.22 \pm 0.89$ \\
\hline
\end{tabular}

Characteristic of PLH is the presence of tricuspid regurgitation (Re on TC). Diagnostic is considered significant $\mathrm{Re}$ on $\mathrm{TC}++$ and $\mathrm{Re}$ on $\mathrm{TC}+++$. Minor degrees of regurgitation were diagnosed more often in the control group $(\mathrm{p}<0.05)$. Re on $\mathrm{TC}++$ occurred equally often in the $1 \mathrm{st}$ and 2nd groups, but significantly more often in premature infants with primary pulmonary hypertension $(34.3 \%)$ than in premature babies of the control group $(5.7 \% ; \mathrm{p} \leq 0.005)$. A high degree of regurgitation was noted in $16(22.9 \%)$ children of the study group and only in $4(5.7 \%)$ controls. Moreover, Re on TC +++ in term infants from the control group was not detected ( $\mathrm{p}<0.005)$. In the groups of premature babies, there are no significant differences in this indicator (Table 5).

Table 5.

THE DEGREE OF TRICUSPID REGURGITATION

\begin{tabular}{|c|c|c|c|c|}
\hline \multirow{2}{*}{ Indicator } & \multicolumn{2}{|c|}{$\begin{array}{c}\text { Children with primary pulmonary } \\
\text { hypertension }\end{array}$} & \multicolumn{2}{|c|}{ Control } \\
\hline & Full-term children & Premature babies & Full-term children & Premature babies \\
\hline $\operatorname{Re}$ on $\mathrm{TC}<+$ & $4(11.4 \%)$ & $3(8.6 \%)$ & - & $16(45.7 \%)$ \\
\hline $\mathrm{Re}$ on $\mathrm{TC}+$ & $18(51.4 \%)$ & $11(31.4 \%)$ & $22(62.9 \%)$ & $13(37.1 \%)$ \\
\hline $\operatorname{Re}$ on $\mathrm{TC}++$ & $6(17.1 \%)$ & $12(34.3 \%)$ & $13(37.1 \%)$ & $2(5.7 \%)$ \\
\hline $\operatorname{Re}$ on $\mathrm{TC}+++$ & $7(20 \%)$ & $9(25.7 \%)$ & - & $4(11.4 \%)$ \\
\hline
\end{tabular}

High pressure in the cavity of the right ventricle (> $25 \mathrm{~mm} \mathrm{Hg}$ ) Was recorded mainly in children of the 1st group (25.7\%), with the same frequency in the groups. In the control group, an increase in pressure in the pancreas was noted only in 32 st group $(7.5 \% ; \mathrm{p}<0.005)$.

Primary pulmonary hypertension affects the reduction of the closure of fetal communications, which, with hypoxic effects, occurs between the ages of 2 months and 1.5 years. Therefore, to assess the dynamics of the normalization of indicators, the reference Doppler EHO-KG study was conducted after 3 months. All the studied children had normalization of the blood flow velocity in the pulmonary artery trunk, closure or reduction in the size of fetal communications, decrease in the degree of Re in TC by this time.

Thus, the only differential diagnostic method for the detection of pulmonary artery in newborns is Doppler EHO-KG. Analyzing the data obtained, it should be noted that in case of mild primary pulmonary hypertension, the systolic function of the ventricles is not disturbed; the dimensions of the cavities can remain within the normal range. The presence of diastolic dysfunction of the ventricles, being a consequence of the transferred hypoxia, reflects adaptation processes of the cardiovascular system. A characteristic ultrasound picture for primary pulmonary hypertension is: the presence of persistent fetal communications, high velocity flows in the 
pulmonary artery stem, the presence of diagnostically significant $\mathrm{Re}$ on $\mathrm{TC}$, high pressure in the cavity of the right ventricle ( $>25 \mathrm{~mm} \mathrm{Hg}$ ), especially in premature newborns.

In all the children we studied, under dynamic observation, after 3 months, there was a decrease to the age norms of the level of velocity flows in the pulmonary artery trunk, closure or reduction in the size of fetal communications, a decrease in the degree of Re by the tricuspid valve, which characterizes the benign course and primary pulmonary hypertension.

\section{Conclusions}

In case of persistent pulmonary hypertension, ECG often reveals signs of hypoxic-ischemic myocardial damage, conduction disturbances (incomplete blockade of the right bundle of His bundle and slowing of $\mathrm{AV}$-conduction), overload of the right ventricle; A typical ultrasound picture for persistent pulmonary hypertension is: high velocity flows $(\geq 1.4-1.6 \mathrm{~m} / \mathrm{s})$ and pressure gradient in the pulmonary artery stem; the presence of diagnostically significant $\operatorname{Re}$ on $\mathrm{TC}(++/+++)$, high pressure in the cavity of the right ventricle $(>25 \mathrm{~mm} \mathrm{Hg}$ ), the presence of persistence of fetal communications.

\section{References:}

1. Platt, J. L., West, L. J., Chinnock, R. E., \& Cascalho M. (2018). Toward a solution for cardiac failure in the newborn. Xenotransplantation, 25(6), 124-138. https://doi.org/10.1111/xen.12479

2. Philip, J., Samraj, R. S., Lopez-Colon, D., Gonzalez-Peralta, R., Chandran, A., \& Bleiwies, M. S. (2018) Severe Direct Hyperbilirubinemia as a Consequence of Right Heart Failure in Congenital Heart Disease. World J Pediatr Congenit Heart Surg, 9(4), 470-474. https://doi.org/10.1177/2150135116640786

3. Simonneau, G., Robbins, I., \& Beghetti, M. (2009). Updated clinical classification of pulmonary hypertension. Journal of the American College of Cardiology, 54(1), S43-S54. https://doi.org/10.1016/j.jacc.2009.04.012

4. Galie, N., Humbert, M., \& Vachieryc, J.-L. (2015). 2015 ESC/ERS Guidelines for the diagnosis and treatment of pulmonary hypertension. European Heart Journal, 46, 903-975. https://doi.org/10.1183/13993003.01032-20155

5. Travis, W. D., Costabel, U., Hansell, D. M., King Jr., T. E., Lynch, D. A., Nicholson, A. G., ..., \& Behr, J. (2013). An official American Thoracic Society/European Respiratory Society statement: update of the international multidisciplinary classification of the idiopathic interstitial pneumonias. American journal of respiratory and critical care medicine, 188(6), 733-748. https://doi.org/10.1164/rccm.201308-1483ST

\section{Список литературы:}

1. Platt J. L., West L. J., Chinnock R. E., Cascalho M. Toward a solution for cardiac failure in the newborn // Xenotransplantation. 2018. V. 25. №6. P. 124-138. https://doi.org/10.1111/xen.12479

2. Philip J., Samraj R. S., Lopez-Colon D., Gonzalez-Peralta R., Chandran A., Bleiwies M. S. Severe Direct Hyperbilirubinemia as a Consequence of Right Heart Failure in Congenital Heart Disease // World J Pediatr Congenit Heart Surg. 2018. V. 9. №4. P. 470-474. https://doi.org/10.1177/2150135116640786

3. Simonneau G., Robbins I., Beghetti M. Updated clinical classification of pulmonary hypertension // J. Am. Coll. Cardiol. 2009. V. 54. P. 43-54. https://doi.org/10.1016/j.jacc.2009.04.012 
4. Galie N., Humbert M., Vachieryc J.-L. 2015 ESC/ERS Guidelines for the diagnosis and treatment of pulmonary hypertension // European Heart Journal. 2015. №46. P. 903-975. https://doi.org/10.1183/13993003.01032-20155

5. Travis W. D., Costabel U., Hansell D. M. An official American Thoracic Society/European Respiratory Society Statement: Update of the international multidisciplinary classification of the idiopathic interstitial pneumonias // Am J Respir. Crit.CareMed. 2013. V. 188. №6. P. 733-748. https://doi.org/10.1164/rccm.201308-1483ST

Работа поступила

в редакиию 20.06.2019 2.
Принята к публикациии

24.06.2019 2.

Ссьлка для изитирования:

Shkarin N., Naumenko E. Aspects of Diagnostics of Neonatal Pulmonary Hypertension in the Premature Newborns // Бюллетень науки и практики. 2019. Т. 5. №7. С. 40-46. https://doi.org/10.33619/2414-2948/44/04

Cite as (APA):

Shkarin, N., \& Naumenko, E. (2019). Aspects of Diagnostics of Neonatal Pulmonary Hypertension in the Premature Newborns. Bulletin of Science and Practice, 5(7), 40-46. https://doi.org/10.33619/2414-2948/44/04 